\title{
The Roles of the Government Internal Control System to Minimize Corruption Through the Fraud Star
}

\author{
Haryono Umar ${ }^{1}$, Ulfah Apriani ${ }^{2} \&$ Rahima Br. Purba ${ }^{3}$ \\ ${ }^{1}$ Perbanas Institute, Jakarta, Indonesia \\ ${ }^{2}$ Department of Accountancy, Faculty of Economics and Business, Trisakti University, Jakarta, Indonesia \\ ${ }^{3}$ Universitas Pembangunan Pancabudi, Medan, Indonesia \\ Correspondence: Haryono Umar, Perbanas Institute, Jakarta, Indonesia.
}

Received: September 3, 2020

Accepted: November 21, 2020

Online Published: March 2, 2021

doi:10.5430/ijfr.v12n3p407

URL: https://doi.org/10.5430/ijfr.v12n3p407

\begin{abstract}
The research discussed a pressure, opportunity, as well as rationalization have a positive effect on corruption. However, the system does not weaken the positive influence of opportunity, rationalization, and ability on corruption neither does the internal control strengthen the negative influence of integrity on corruption. Therefore, SPIP in the Supreme Court of the Republic of Indonesia must be able to adapt to the COSO theory since the Court is a government body that is specifically characterized as a law enforcing authority to decide a case in court.
\end{abstract}

Keywords: fraud star, government internal control system, corruption, the supreme court of the Republic of Indonesia

\section{Introduction}

In Indonesia, rampant corruption is currently occurring not only at the central but also at the regional level. Unfortunately, regional autonomy may enable municipal officials to use any opportunity to commit corruption by abusing their authority. It is not surprising that corruption is unavoidable news on printed, electronic, and online media. Therefore, the role of the KPK in revealing the causes of corruption which can occur in the public, private, and BUMN/ BUMD sectors is very critical.

According to the 2016 Indonesian Fraud Survey (Association of Certified Fraud Examiner (ACFE), 2017), corruption was the most commonly committed fraud, accounting for $67 \%$ or 154 out of a total of 229 respondents. Based on the official website KPK (kpk.go.id) alone, the corruption cases attributed to profession/position basis, 21 judges had been arrested by the KPK taking place throughout Indonesia from 2011 to 2018. An example of corruption cases was bribery involving a defendant one (I) who was named Suryana and the second one (II) whose name was Hendra Kurniawan, and the Public Prosecutor of the case was the KPK, Case Number: No: 61/Pid.Sus-TPK/2017/PN Bgl, date of registration: November 15, 2017, the decision on February 14, 2018. Results of the decision were: Defendant one (I) was a 7-year sentence in prison with a fine of Rp. 200,000,000, 00 (two hundred million rupiahs) with the provisions that if not paid substituted for four-month imprisonment. Meanwhile, the second defendant (II) was a 5-year and 6-month sentence in prison with a fine of Rp. 200,000,000.00 (two hundred million rupiahs) provided that if not paid it will be substituted with 4 months of imprisonment (Source: sipp.pn-Bengkulu.go.id).

Albrecht et al. (2012) and Umar et al. (2019) suggested that the main element in some fraud cases which is frequently found is the aspect of internal control. When it is either absent or changes, it will result in greater opportunity and risk of fraud. Therefore, it is very critical that the government's internal control system is established to minimize the fraud occurrence(Albrecht, Albrecht, Albrecht, \& Zimbelman, 2012; Haryono Umar \& Purba, 2019).

Again, this research was carried out in Indonesia given that there are still many phenomena of fraud, particularly in the form of recurring corruption which is often committed by judges and the officials of the Supreme Court of the Republic of Indonesia. Therefore, the present study is further improved research which was conducted by Sanusi et al. (2015) entitled 'Effects of Internal Controls, Fraud Motives, and Experience in Assessing the Likelihood of Fraud Risk', indicating the results that the deceit element in the 'fraud triangle' significantly influences the occurrence of fraud. There is a significant influence among internal control and fraud motivational factors (pressure, opportunity, and rationalization)(Mohd-Sanusi, Mohamed, Omar, \& Mohd-Nassir, 2015). 
The results of this study are beneficial for scientifically theoretical contributions to the study of Fraud star against corruption. It takes into account the government's internal control system as a moderating variable in the case study of the Supreme Court of the Republic of Indonesia. There still lacks studies on Fraud star; thus, the research is expected to be a new reference in the field of forensic/investigative audits, particularly regarding corruption, the practice of providing benefits through the analysis presented at the Supreme Court of Indonesia to be able to provide references and insight associated with pressure, opportunity, rationalization, ability, integrity, government internal control system, corruption, and policies. Furthermore, the study's results can be used as a reference to establish internal policies to minimize the occurrence of corruption within the Supreme Court. Strategies must be made to create a highly accountable, transparent state institution with high integrity.

\section{Related Literature and Hypotheses}

This current research used Agency theory which was proposed by Jensen and Meckling (1976) as the main theory. Agency theory deals with the contractual relationships between the members of a company. It is the agency relationship arising from a contract between the owner (principal) and the manager (agent) in providing services and then delegating the decision-making authority(Jensen \& William H.Meckling, 1976).

Institutions/organizations have been granted their rights in the form of salary regularly and other facilities from the principle, i.e. the government, enabling the agent/agency to carry out its duties and perform its proper functions. On the other hand, the government as a principle receives information from its agents in the form of reports on the implementation of each activity it has carried out. However, the information it provides is sometimes not by the implementation of activities that have been mandated by the principle (the government), leading to conflict of interest.

Therefore, the conflict of interest may arise because the agency is assigned as the executive body of the rules set by the government. The agency is controlled in carrying out its activities and it has the opportunity to manage the activities provided by the government. Since it is responsible for the rationalization of the implementation of activities, the agency is attributed to a great opportunity as an entrance to corruption.

Therefore, integrity is required in each agent to prevent corruption. It is also crucial to establish a government internal control system to minimize corruption. There is an agency problem between the government and agents which leads to corruption. The absence of a good and effective government internal control system causes the government/ principle to incur a loss while it results in a wide opportunity for the agents to commit corruption. It is also critical that the integrity of the agent is upheld in running every activity mandated by the government to prevent corruption.

Isgiyata et al. (2018) revealed the results in his study that exposes (weak punishment) and the lack of leadership's idealism would increase the potential for fraud in the procurement of government goods/services(Isgiyata, Indayani, \& Budiyoni, 2018). In other words, if the punishment does not cause a deterrent effect nor is the leader idealistic, it will result in a greater potential for fraud. Moreover, Hasanah and Diana (2018) stated that Diamond fraud (pressure, opportunity, rationalization, and ability) and GONE theory (greed, opportunity, needs, and disclosure) simultaneously and partially had a significantly positive effect on academic fraud (Hasanah \& Diana, 2018).

Fraud is a deliberate act carried out by an individual or a group of people in various forms that can be detrimental to another person or group of other parties. Fraud can be interpreted in detail such as lying, cheating, falsification, deception, embezzlement of goods, information misrepresentation, manipulation, tampering with evidence/spoliation of evidence, and distortion of facts.

According to Umar in 'Corruption the Devil', he stated that fraud is interpreted as a form of deceit that occurs in organization management including its resources, such as deliberate fraud, office assets misuse, falsification of accounts, deception, misappropriation of organizations with various aspects which do not have basic justification(Haryono Umar, 2016). Aksa (2018) argued that fraud is a planned lie either manipulating financial statements or actions which benefit themselves, a group, or an organization(Aksa, 2018).

Association of Certified Fraud Examiners (2016) divided fraud into three types based on the actions commonly known as "fraud trees", namely: asset misappropriation, fraudulent statements, and corruption. Meanwhile, the components of Fraud star which drive fraud (Cressey, 1964; Siahaan, Umar, \& Purba, 2019; Yusof, Khair, \& Simon, 2013) (Cressey, 1953 and Siahaan et al, 2019) are:

1. Pressure. Pressure, according to the Great Dictionary of Indonesian Language (KBBI), is a state (result) of the force of pressing, coercion, and strong force (https://kbbi.web.id). Zamzam et al. (2017) revealed that pressure has a positive effect on the level of fraud. This research was conducted at a university to detect academic cheating(Zamzam, Mahdi, \& Ansar, 2017). Furthermore, according to the research conducted by Sanusi et al. (2015), 
pressure has several dimensions, such as pressure in finance, bad habits, the pressure at workplace, and external pressure(Mohd-Sanusi et al., 2015).

2. Opportunity. According to the Great Dictionary of Indonesian Language (KBBI), the opportunity is time, chance owned by someone. In the study conducted by Abdullahi and Mansor (2018), they found that opportunity has a positive relationship with the occurrence of fraud in the Nigerian public sector. A fraud that occurred in the country resulted from the opportunity of perpetrators to commit fraud. An opportunity has dimensions, namely compliance with control, poor quality of performance, indisciplined, lack of information, inability, and negligence, and the absence of audit track record. (Abdullahi \& Mansor, 2018)

3. Rationalization. According to Umar (2017: 514), rationalization is an appropriate attitude owned by an individual by doing creativity to implement the rules by their presumption, not based on how the actual rules. Zamzam et al. (2017) revealed that rationalization had no positive effect on the level of fraud. This research was conducted at the university by detecting academic cheating. Rationalization has a dimension that is the reason for rationalization.

4. Ability. Ruankaew (2016) explained that someone who can manage and take advantage of existing opportunities is more likely to commit fraud(Ruankaew, 2016). While various factors have an impact on an individual to commit fraud, the government can prevent/minimize it. According to Umar (2017: 520), the ability is something that a person possesses because he/she has power or authority and the opportunity to commit corruption. Furthermore, the ability has dimensions, i.e. position, resistance to pressure/stress, self-confidence/selfishness, coercion, fraud, and intelligence(Haryono Umar, 2016).

5. Integrity. Wulandari and Nuryatno (2018) stated that internal control, integrity, independence, and professionalism have a positive effect on fraud prevention, while anti-fraud awareness does not have a positive effect on fraud prevention(Wulandari \& Nuryanto, 2018). According to Umar (2016: 524) in 'Corruption the Devil', integrity is a professional and honest attitude, by which, a person carrying out the duties and obligations has a firm stand no matter the tasks he performs are being supervised or not. Integrity consists of two dimensions, namely internal and external factors.

\subsection{Government Internal Control System (SPIP)}

The government's internal control system had a positive effect on the application of accrual-based accounting. Meanwhile, the internal audit did not affect accounting implementation(Haryono Umar; Muhammad Irsan Nasution, 2018; H. Umar, Usman, \& Purba, 2018). The application of accrual-based accounting had a positive effect on corruption prevention. Likewise, the government's internal control system had a positive influence on corruption prevention and so did the internal audit. The government's internal control system influenced the prevention of corruption through the application of accrual-based accounting while internal audit did not. The SPIP aims to achieve effective, efficient, transparent, and accountable state financial management. Therefore, ministers/heads of institutions, governors, and regents/mayors are required to exercise their control over the governmental administration activities by PP 60/2008 Article 2 paragraph 1. The SPIP is comprised of dimensions, such as the controlling environment, risk assessment, control activities, information and communication, and internal control monitoring.

\subsection{Corruption}

Corruption is a misuse of public office in the government sectors for personal gain (Tuanakota, 2010). It is a problem which developing countries often encounter due to poor law enforcement and still lack of awareness of good governance. Therefore, the integrity factor is in question. The dimension of corruption is bribery.

Conceptual Framework

\begin{tabular}{ll}
\hline \multicolumn{2}{l}{ Fraud star $(\mathbf{X})$} \\
\hline$\bullet$ & Pressure (PR) \\
\hline$\bullet$ & Opportunity (KS) \\
\hline$\bullet$ & Rationalization (RS) \\
\hline$\bullet$ & Ability (KM) \\
\hline$\bullet$ & Integrity (IT) \\
\hline
\end{tabular}




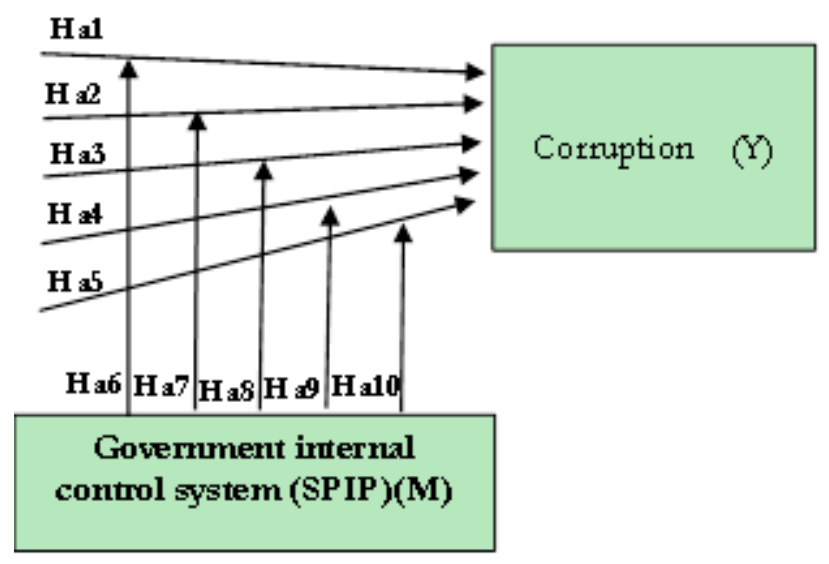

Figure 1. Conceptual framework of the research

The hypotheses of the study are as follows:

Ha1: Pressure has a positive effect on corruption;

Ha2: Opportunity affects positively corruption;

Ha3: Rationalization has a positive effect on corruption;

Ha4: Ability has a positive effect on corruption;

Ha5: Integrity has a negative influence on corruption;

Ha6: Government's Internal Control System weakens the positive influence of pressure on corruption;

Ha7: Government's Internal Control System weakens the positive influence of opportunity on corruption;

Ha8: Government's Internal Control System weakens the positive influence of rationalization on corruption;

Ha9: Government's Internal Control System weakens the positive influence of ability on corruption;

Ha10: Government Internal Control System strengthens the negative influence of integrity on corruption.

\section{Research Methods}

\subsection{Definition and Measurement of Variables}

\subsubsection{Independent Variable}

Pressure is an act which a person feels as a result of either originating his inner or outer factor in certain situations and conditions so that it urges him to commit fraud or deviations (Tuanakotta, 2017). Meanwhile, an opportunity is an action someone performs because there is a chance to commit fraud in his office due to weak control (Albrecht et al., 2012). Furthermore, rationalization is a necessary part of the crime itself, a part that motivates someone to commit the crime. The rationalization is required so that the actor can justify his actions, despite against the law, to maintain his presumption as a trusted person. After committing the crime, the actor abandons the rationalization because it is no longer required. Moreover, the ability is defined as a state in which someone can manage the opportunities which exist and take benefit from them. Finally, integrity is an attitude based on professionalism and honesty in performing something or actions.

\subsubsection{Dependent Variable}

Corruption, according to Law of the Republic of Indonesia Number 31 of 1999 in conjunction with Law Number 20 of 2001 concerning Eradication of Corruption, is any person who unlawfully commits acts for the gain of himself or others or a corporation that can harm the state's finances or economy, shall be sentenced to imprisonment with life imprisonment or imprisonment for a minimum of 4 (four) years and a maximum of 20 (twenty) years and a fine of no less than Rp. 200,000,000.00 (two hundred million rupiahs) and a maximum of Rp1,000,000. 000.00 (one billion rupiahs).

\subsubsection{Moderating Variable}

The Government Internal Control System (SPIP) has the objective of providing adequate assurance in achieving the 
effectiveness and efficiency of achieving the objectives of the administration of the State, reliability of financial reporting, safeguarding State's assets, and adherence to laws and regulations, by PP 60/2008 Article 2 paragraph 3.

In this study, the data collection used survey methods by distributing questionnaires to the respondents, in which a sample response to each question was asked. The population is all units within an organization in a certain scope that meet the criteria for research questions and discussions. The population of this research was civil servants who had been working at the Supreme Court of the Republic of Indonesia as judicial institutions. There were a total of 31,000 employees who worked at the Court; however, this study only took the judges, employees, and auditors. The respondents must meet the criteria, such as judges at the district court in DKI Jakarta, employees of the Supreme Court of the Republic of Indonesia, and auditors of the Supreme Court Supervisory Agency of the Republic of Indonesia.

This research was conducted using a sample size based on Sekaran (2016), by which the minimum sample size was 30 and a maximum of 500 by multivariate research (Sekaran \& Bougie, 2016). This study has seven variables consisting of five independent variables, one dependent variable, and one moderating variable which was divided into 45 indicator questions in the questionnaire. The minimum number of samples to be achieved was 225 respondents which were obtained from the multiplication of samples 5 (five) times 45 indicators. The sampling used convenience sampling method by which the criteria of the respondents for the study had been determined.

\subsection{Data Analysis Method}

The research used the approach of partial least square analysis (PLS version 3.0), which is an example of structural equation modeling (SEM) based on components or variants. PLS is another optional approach that shifts from SEM-based covariance approach (testing causality or theory) to variants, which exhibit predictive models and powerful nature(Ghozali \& Fuad, 2014). Measurement models were performed using convergent validity, discriminant validity, and average variance extracted (AVE)/reliability tests. Meanwhile, the inner model in this research was $\mathrm{R}^{2}, \mathrm{Q}^{2}$, GoF, and bootstrapping method. To test the hypotheses, the study employed moderation effects and direct effects. Finally, the moderated structural equation modeling equation can be observed in the following equation model

$$
\begin{gathered}
\mathrm{KR}=\alpha+\beta 1 \mathrm{PR}+\beta 2 \mathrm{KS}+\beta 3 \mathrm{RS}+\beta 4 \mathrm{KM}+\beta 5 \mathrm{IT}+\beta 6 \mathrm{SPIP}+\beta 7 \mathrm{PR} * \mathrm{SPIP}+\beta 8 \mathrm{KS} * \mathrm{SPIP}+\beta 9 \mathrm{RS} * \mathrm{SPIP}+\beta 10 \mathrm{KM}^{*} \\
\mathrm{SPIP}+\beta 11 \mathrm{IT} * \mathrm{SPIP}+\varepsilon
\end{gathered}
$$

Where:

KR: corruption variable

PR: pressure variable

KS: opportunity variable

RS: rationalization variable

KM: ability variable

IT: integrity variable

SPIP: Government Internal Control System variable

\section{Results and Discussions}

The objects in this study were 31,000 employees of the Supreme Court of the Republic of Indonesia (Supreme Court Civil Service Bureau, 2018). The method used is convenience sampling where only Judges and Substitute Registrars are in the Central Jakarta District Court, West Jakarta District Court, South Jakarta District Court, and East Jakarta District Court and Employees in the Equipment and Auditor Bureau at the Supreme Court Supervisory Agency of the Republic of Indonesia, where sampling limits the minimum is 225 respondents. 
Table 1. Distribution of research samples

\begin{tabular}{lll}
\hline No. & Supreme Court of RI & No. of respondents \\
\hline 1. & Surrogate judge and registrar at the Central Jakarta District Court & 41 \\
\hline 2. & Surrogate judge and registrar at the West Jakarta District Court & 42 \\
\hline 3. & Surrogate judge and registrar at the South Jakarta District Court & 35 \\
\hline 4. & Surrogate judge and registrar at the East Jakarta District Court & 40 \\
\hline 5. & Auditors at the Supervisory Board & 11 \\
\hline 6. & Staff at the Supplies Bureau & 61 \\
\hline Total & & $\mathbf{2 3 0}$ \\
\hline
\end{tabular}

\subsection{Measurement Model Analysis (Outer Model)}

Before testing the hypotheses to predict relationships between latent variables in a structural model, the analysis on measurement model evaluation it was first carried out to verify the indicators and latent variables that can be further tested. Reliability indicators showed several indicators of variance which can be explained by latent variables. a reliability indicator, a reflective indicator must be eliminated (removed) out of the measurement model when the value of outer loading is less than 0.60 . The values of third outer loading are as follows:

Table 2. Value of third outer loading

\begin{tabular}{lll}
\hline Indicator & Value of outer loading & $\mathbf{N}$ \\
\hline PR.4 & 0.697 & 230 \\
\hline PR.5 & 0.647 & 230 \\
\hline PR.6 & 0.774 & 230 \\
\hline PR.7 & 0.742 & 230 \\
\hline PR.8 & 0.737 & 230 \\
\hline PR.9 & 0.677 & 230 \\
\hline KS.10 & 0.790 & 230 \\
\hline KS.13 & 0.692 & 230 \\
\hline KS.14 & 0.789 & 230 \\
\hline RS.17 & 0.866 & 230 \\
\hline RS.18 & 0.872 & 230 \\
\hline RS.19 & 0.858 & 230 \\
\hline RS.20 & 0.800 & 230 \\
\hline KM.21 & 0.810 & 230 \\
\hline KM.24 & 0.853 & 230 \\
\hline KM.25 & 0.748 & 230 \\
\hline IT.27 & 0.741 & 230 \\
\hline IT.28 & 0.821 & 230 \\
\hline IT.29 & 0.699 & 230 \\
\hline IT.30 & 0.716 & 230 \\
\hline IT.31 & 0.704 & 230 \\
\hline IT.32 & 0.679 & 230 \\
\hline & & \\
\hline
\end{tabular}




\begin{tabular}{lll}
\hline SPIP.33 & 0.628 & 230 \\
\hline SPIP.34 & 0.707 & 230 \\
\hline SPIP.36 & 0.726 & 230 \\
\hline SPIP.37 & 0.846 & 230 \\
\hline SPIP.38 & 0.849 & 230 \\
\hline SPIP.39 & 0.719 & 230 \\
\hline SPIP.40 & 0.802 & 230 \\
\hline SPIP.41 & 0.784 & 230 \\
\hline SPIP.42 & 0.826 & 230 \\
\hline KR.43 & 0.907 & 230 \\
\hline KR.44 & 0.961 & 230 \\
\hline KR.45 & 0.943 & 230 \\
\hline
\end{tabular}

Based on Table 2 above, it shows that more than $60 \%$ of the variants on the seven indicators, i.e. PR.3, PR.4, PR.5, PR.6, PR.7, PR.8 and PR.9 which can explain the variable 'pressure' have the least value of 0.647 or $64.7 \%$. The variable 'opportunity' at KS.10, KS.13 and KS.14 indicates that the least value of variable 'opportunity' is 0.692 or $69.2 \%$. meanwhile, the least value of variable 'rationalization' in RS.17, RS.18, RS.19 and RS.20 is 0800 or $80.0 \%$. Furthermore, the least value of variable 'ability' at KM.25 indicates 0.748 or $74.8 \%$ and that of 'integrity in IT.32 is 0.679 or $67.9 \%$. The variable of Government Internal Control System (SPIP) has the least value in SPIP.33, indicating 0.628 or $62.8 \%$. Finally, the variable 'corruption' has the least value of 0.909 or $90.9 \%$ at KR.43.

a) Convergent validity (composite reliability and AVE measurement model)

Table 3. Value of composite reliability and AVE measurement model

\begin{tabular}{llll}
\hline Variable & Cronbach's Alpha & Composite Reliability & Average variance extracted (AVE) \\
\hline PR & $0.812>0.6$ & $0.861>0.7$ & $0.509>0.5$ \\
\hline KS & $0.645>0.6$ & $0.802>0.7$ & $0.575>0.5$ \\
\hline RS & $0.872>0.6$ & $0.912>0.7$ & $0.722>0.5$ \\
\hline KM & $0.734>0.6$ & $0.846>0.7$ & $0.648>0.5$ \\
\hline IT & $0.823>0.6$ & $0.871>0.7$ & $0.530>0.5$ \\
\hline SPIP & $0.912>0.6$ & $0.928>0.7$ & $0.590>0.5$ \\
\hline KR & $0.931>0.6$ & $0.956>0.7$ & $0.879>0.5$ \\
\hline
\end{tabular}

Based on the values of composite reliability presented in the table above, it shows that the six latent variables have Cronbach's alpha values and composite reliability above 0.60 and 0.70 . That is, the latent variable (construct) is very robust or it can be said that the five measurement models are reliable. The robustness of convergent validity value is indicated by the higher correlation between indicators which compose a construct.

The AVE value shown in the table above indicates that the seven latent variables have the AVE values above the minimum criteria, which is 0.50 ; therefore, the convergent validity size is good or it can be said to have met the convergent validity criteria (Ghozali \& Fuad, 2014).

b) Assessment of discriminat validity 
Table 4. Discriminat validity

\begin{tabular}{llllllll}
\hline Variable & IT & KM & KR & KS & PR & RS & SPIP \\
\hline IT & 0.728 & & & & & & \\
\hline KM & -0.334 & 0.805 & & & & & \\
\hline KR & -0.482 & 0.356 & 0.937 & & & & \\
\hline KS & 0.248 & 0.088 & -0.324 & 0.759 & & & \\
\hline PR & -0.367 & 0.467 & 0.353 & -0.107 & 0.713 & & \\
\hline RS & -0.302 & 0.056 & 0.430 & -0.303 & 0.065 & 0.850 & \\
\hline SPIP & 0.566 & -0.412 & -0.499 & 0.398 & -0.482 & -0.259 & 0.768 \\
\hline
\end{tabular}

Based on Table 4, it shows that almost all the AVE root values in the construct are greater than the correlation between other constructs. Given such, it can be said that discriminat validity is reliable. Discriminant validity can also be measured by observing the cross loading measurements with the construct in the table as follows:

Table 5. Cross loading

\begin{tabular}{llllllll}
\hline Indicator & IT & KM & KR & KS & PR & RS & SPIP \\
\hline IT.27 & 0.741 & -0.182 & -0.325 & 0.190 & -0.304 & -0.234 & 0.437 \\
\hline IT.28 & 0.821 & -0.256 & -0.376 & 0.167 & -0.278 & -0.161 & 0.412 \\
\hline IT.29 & 0.699 & -0.245 & -0.304 & 0.141 & -0.302 & -0.108 & 0.292 \\
\hline IT.30 & 0.716 & -0.238 & -0.290 & 0.065 & -0.221 & -0.091 & 0.251 \\
\hline IT.31 & 0.704 & -0.288 & -0.404 & 0.209 & -0.240 & -0.332 & 0.511 \\
\hline IT.32 & 0.679 & -0.235 & -0.377 & 0.274 & -0.260 & -0.336 & 0.503 \\
\hline KM.21 & -0.225 & 0.810 & 0.310 & 0.127 & 0.399 & 0.163 & -0.322 \\
\hline KM.24 & -0.330 & 0.853 & 0.323 & 0.027 & 0.382 & -0.052 & -0.371 \\
\hline KM.25 & -0.247 & 0.748 & 0.199 & 0.056 & 0.343 & 0.020 & -0.294 \\
\hline KR.43 & -0.392 & 0.319 & 0.907 & -0.234 & 0.393 & 0.313 & -0.418 \\
\hline KR.44 & -0.459 & 0.303 & 0.961 & -0.311 & 0.312 & 0.413 & -0.472 \\
\hline KR.45 & -0.495 & 0.373 & 0.943 & -0.352 & 0.298 & 0.466 & -0.503 \\
\hline KS.10 & 0.239 & 0.104 & -0.282 & 0.790 & -0.016 & -0.147 & 0.254 \\
\hline KS.13 & 0.027 & 0.129 & -0.154 & 0.692 & -0.179 & -0.221 & 0.204 \\
\hline KS.14 & 0.233 & -0.007 & -0.268 & 0.789 & -0.097 & -0.329 & 0.418 \\
\hline PR.4 & -0.328 & 0.366 & 0.311 & -0.105 & 0.697 & 0.036 & -0.360 \\
\hline PR.5 & -0.290 & 0.402 & 0.174 & 0.086 & 0.647 & -0.025 & -0.312 \\
\hline PR.6 & -0.262 & 0.381 & 0.207 & -0.022 & 0.774 & -0.033 & -0.406 \\
\hline PR.7 & -0.294 & 0.296 & 0.317 & -0.186 & 0.742 & 0.116 & -0.303 \\
\hline PR.8 & -0.199 & 0.348 & 0.248 & -0.070 & 0.737 & 0.067 & -0.382 \\
\hline PR.9 & -0.149 & 0.203 & 0.166 & -0.068 & 0.677 & 0.079 & -0.303 \\
\hline RS.17 & -0.154 & 0.044 & 0.363 & -0.265 & 0.063 & 0.866 & -0.184 \\
\hline RS.18 & -0.323 & 0.051 & 0.430 & -0.307 & 0.040 & 0.872 & -0.275 \\
\hline RS.19 & -0.275 & 0.097 & 0.337 & -0.181 & 0.097 & 0.858 & -0.184 \\
\hline & & & & & & & \\
\hline
\end{tabular}




\begin{tabular}{llllllll}
\hline Indicator & IT & KM & KR & KS & PR & RS & SPIP \\
\hline RS.20 & -0.268 & -0.006 & 0.312 & -0.267 & 0.024 & 0.800 & -0.228 \\
\hline SPIP.33 & 0.381 & -0.356 & -0.294 & 0.120 & -0.360 & -0.033 & 0.628 \\
\hline SPIP.34 & 0.505 & -0.381 & -0.372 & 0.210 & -0.445 & -0.114 & 0.707 \\
\hline SPIP.36 & 0.337 & -0.260 & -0.293 & 0.304 & -0.379 & -0.109 & 0.726 \\
\hline SPIP.37 & 0.489 & -0.366 & -0.391 & 0.353 & -0.347 & -0.214 & 0.846 \\
\hline SPIP.38 & 0.512 & -0.264 & -0.406 & 0.358 & -0.391 & -0.205 & 0.849 \\
\hline SPIP.39 & 0.328 & -0.311 & -0.339 & 0.347 & -0.389 & -0.289 & 0.719 \\
\hline SPIP.40 & 0.389 & -0.255 & -0.324 & 0.370 & -0.391 & -0.221 & 0.802 \\
\hline SPIP.41 & 0.414 & -0.309 & -0.526 & 0.341 & -0.344 & -0.299 & 0.784 \\
\hline SPIP.42 & 0.518 & -0.348 & -0.406 & 0.309 & -0.322 & -0.227 & 0.826 \\
\hline
\end{tabular}

Based on Table 5 above, shows that the constructs of pressure are high on the indicators PR.4, PR.5, PR.6, PR.7, PR.8, and PR.9 and have good discriminate validity. The constructs of opportunity are also high for its indicators of KS.10, KS.13, and KS.14, and have good discriminant validity. The constructs of rationalization are high on the indicators of RS.17, RS.18, RS.19, and RS.20, and they have good discriminant validity.

The construct of ability is high for indicators of KM.21, KM.24, and KM.25 and they have good discriminant validity. Meanwhile, the constructs of integrity are high for the indicators of IT.27, IT.28, IT.29, IT.30, IT.31, and IT.32, and have good discriminant validity.

The constructs of the Government Internal Control System (SPIP) are high on the indicators of SPIP.33, SPIP.34, SPIP.36, SPIP.37, SPIP.38, SPIP.39, SPIP.40, SPIP.41, and SPIP.42 and have good discriminant validity. Finally, the constructs of corruption are also high on the indicators of KR.43, KR.44, and KR.45, and have good discriminant validity.

\subsection{The Structural Model or Inner Model Evaluation}

The structural or inner model is that which describes the relationship between latent variables. The structural models are evaluated using path parameter coefficients, R2, f2, Q2, and GoF (Hair et al., 2013). Subsequently, the evaluation of the feasibility test of the model was performed using the value of R2 with 0.446 . The figure explains that the variability of endogenous variables which can be explained by the variability of exogenous variables is $44.6 \%$.

In addition to examining the R-square, an evaluation of the effect of endogenous variables on the known exogenous variables based on the effect size value of $\mathrm{f} 2$ was also conducted. The values are presented in the following table.

Table 6. F-Square values for each exogenous latent variables

\begin{tabular}{lll}
\hline Causality relationship & F-Square & Remarks \\
\hline PR & 0.023 & Weak \\
\hline KS & 0.023 & Weak \\
\hline RS & 0.112 & Intermediate \\
\hline KM & 0.036 & Weak \\
\hline IT & 0.033 & Weak \\
\hline SPIP & 0.022 & Weak \\
\hline
\end{tabular}

Based on Table 6 above, it shows that the values of effect size $\mathrm{f} 2$ on each exogenous latent variable are positive with varied strength of the relationship between exogenous latent variables starting from the weak to medium relationship. It can be inferred that despite the variations in strength between exogenous latent variables, it can simultaneously explain the variability of endogenous latent variables. The value of Q2 obtained is 0.346 , which is greater than 0 ; therefore, the structural model has a predictive relevance. The GoF value is obtained from the equation as follows: 


$$
\begin{gathered}
\text { Gof }=\sqrt{\overline{A V E} * \overline{R^{2}}} \\
\text { Gof }=\sqrt{0.636 * 0.446} \\
\text { Gof }=0.532
\end{gathered}
$$

Using manual calculation of Gof in this study, the value of 0.532 is greater than 0.346 . Thus, the model in this study has a high reliability in explaining the empirical data.

\subsection{Hypothesis Testing}

Hypothesis testing was performed to investigate the effect of a construct on other constructs by evaluating the parameter coefficient and t-statistic value. In testing hypotheses, the study used the value contained in the path coefficient or path coefficient to test the inner model as the basis. The results of the hypothesis are proposed by looking at the magnitude of the t-statistic.

The t-statistic value which was compared to those of the t-table determined in this study was 1.650 where the df value was 230 (the number of samples minus two $=230-2$ ) and alpha at a significance level of 0.05 (one-tailed). The limit for accepting and rejecting the proposed hypotheses is \pm 1.650 . If the statistic value is in the range of -1.655 to 1.655 , the hypothesis will be rejected. In other words, the null hypothesis (Ho) is accepted. The results of the structural path coefficients and t-statistic values obtained through the bootstrapping process with the number of samples for resampling 230 and 1000 repetitions are shown in the following table.

Table 7. Structural model path coefficients (SPIP moderation)

\begin{tabular}{llllll}
\hline Causality relationship & Expectation & Original Sample & P-Values & Conclusion & Remarks \\
\hline PR $->$ KR & Positive & 0.168 & 0.033 & Ha1 accepted & Effective \\
\hline KS -> KR & Positive & 0.154 & 0.014 & Ha2 accepted & Effective \\
\hline RS -> KR & Positive & 0.299 & 0.039 & Ha3 accepted & Effective \\
\hline KM $->$ KR & Positive & 0.190 & 0.004 & Ha4 accepted & Effective \\
\hline IT $>$ KR & Negative & -0.173 & 0.014 & Ha5 accepted & Effective \\
\hline PR*SPIP -> KR & Negative & -0.134 & 0.022 & Ha6 accepted & weakening \\
\hline KS*SPIP -> KR & Negative & -0.009 & 0.451 & Ha7 rejected & Not weakening \\
\hline RS*SPIP -> KR & Negative & -0.012 & 0.454 & Ha8 rejected & Not weakening \\
\hline KM*SPIP -> KR & Negative & -0.029 & 0.339 & Ha9 rejected & Not weakening \\
\hline IT*SPIP -> KR & Negative & -0.139 & 0.075 & Ha10 rejected & Not strengthening \\
\hline
\end{tabular}

Significance level $=5 \%$ (One-Tiled $)$

$$
\begin{gathered}
\mathrm{KR}=\beta 10,168 \mathrm{PR}+\beta 20,154 \mathrm{KS}+\beta 30,299 \mathrm{RS}-\beta 40,190 \mathrm{KM}-\beta 50,173 \mathrm{IT}-\beta 60,160 \mathrm{SPIP}-\beta 70,134 \mathrm{PR} * \mathrm{SPIP}- \\
\beta 80,009 \mathrm{KS}^{*} \mathrm{SPIP}-\beta 90,012 \mathrm{RS} * \mathrm{SPIP}-\beta 100,029 \mathrm{KM}^{*} \mathrm{SPIP}-\beta 110,139 \mathrm{IT} * \mathrm{SPIP}
\end{gathered}
$$

\section{Discussions}

\subsection{Pressure Toward Corruption}

Pressure has a positive effect on committing corruption. The results of this study proved that pressure is one of its driving factors. The pressure occurred because of necessity (such as high lifestyle), greed and weak punishment for corruptors. It indicates that the judges and the Court employees felt pressure both from inside and outside themselves in carrying out their duties and functions. 
Therefore, it results in high rate of corruption. The pressure the Court employees encountered due to high lifestyle caused the extravagant needs, there is a sense of greed in their heart which impacted to committing corruption. The study results are in line with the theory proposed by Albrecht (2012) stating that when a person has high either inner or outer pressure, the higher the desire of committing corruption. Several studies support these results, such as that of Sanusi et al. (2015). They also stated that, if someone is depressed the particular person will be driven to commit corruption. Similarly, research conducted by Abdullahi and Mansor (2018) stated that pressure has a positive relationship with the occurrence of fraud in the Nigerian public sector.

\subsection{Opportunities for Corruption}

An opportunity has a positive effect on corruption. The results of this study proved that opportunity is one of the driving factors to corruption. Opportunities exist because there is an intention from the perpetrators and they have the opportunity to commit corruption due to poor internal control. Also, the opportunity arises because of the need and greed of the corruptors, triggering the intention of committing corruption. In such a case, it means that judges and court employees carried out their duties not by the mandate granted by the government and they also have an intention to commit corruption.

As such, information asymmetry arises between these two parties. This result is in line with the research conducted by Albrecht (2012), revealing that opportunities influence someone to commit corruption. Sanusi et al. (2015) also stated in their research that opportunity has a positive effect on corruption. Similarly, the results of the research conducted by Abdullahi and Mansor (2018) revealed that opportunity has a positive relationship with fraud in the Nigerian public sector.

\subsection{Rationalization of Corruption}

Rationalization has a positive effect on corruption and it is proven as one of the driving factors. Rationalization took place because the corruptors presumed that what was done was usually based on their logic which should be based on the applicable law. It arises because of greed, extravagant necessity (high lifestyle), weak punishment, making the perpetrators of corruption became commonplace.

Judges and the Court officials considered that receiving something in the form of goods from someone else is an expression of gratitude which is considered normal or usual. Therefore, there was information asymmetry in such a case. This finding is in line with research conducted by Albrecht (2012) that rationalization has a positive effect on corruption. Furthermore, there are also several studies that support these findings, such as that of Sanusi et al. (2015) in which they found that rationalization has a positive effect on corruption. Likewise, Abdullahi and Mansor (2018) stated that rationalization has a positive relationship with the incidence of fraud in the Nigerian public sector.

\subsection{Ability to Corruption}

The ability to have a positive effect on corruption and it is proven that this aspect is one of the driving factors, by which an individual is driven to commit corruption. The ability of judges to decide a law case and the Court employees to carry out their duties made it the driving factor for committing corruption. Likewise, the administration staff was also driven to commit corruption due to the opportunity they had. Also, the factors of opportunity, greed, and needs together with the abilities of judges and the Court officials made them in carrying out their duties and functions, not by the mandate of the government.

Also, judges and Court employees have the opportunity to carry out their exclusive duties and functions which cannot be performed by other agencies, such as in deciding a case in a court of law. Besides, judges and the Court employees must have special competence so that the opportunity becomes even greater for corruption. The results of this study are in line with the results of the research conducted by Wolfe and Hermason (2004) where the ability has a positive effect on corruption. Similarly, the research conducted by Ruankew (2016) also revealed that the ability positively influence to commit corruption. Furthermore, research conducted by Zamzam et al. (2017) also revealed that ability has a positive effect on the level of academic cheating.

\subsection{Integrity Against Corruption}

Integrity hurts corruption. In such a case, pressure, opportunity, rationalization, abilities of judges and the Court officials are caused by greed, extravagant needs (grandeur lifestyle), and weak punishment, resulting in vanishing integrity of judges and the Court employees. They presumed it usual when judges and the Court employees received something from other parties related to their duties and functions. At that time, the judge and court staff lose their integrity (lack of integrity). Agents (the Supreme Court) should carry out their duties and functions by established SOP (Standard Operating Procedures). Thus, it will not lead to information asymmetry and it can minimize the 
occurrence of corruption. The higher the integrity one has, the lower probability the corruption can occur.

This finding is in line with that of the research conducted by Alam which found that integrity negatively influences committing corruption. Likewise, the research conducted by Dewi and Ratnadi revealed that integrity negatively influences the tendency of accounting fraud at SKPD, the City of Denpasar, Bali, Indonesia.

\subsection{The Government Internal Control System (SPIP) Moderates the Effect of Pressure on Corruption}

A variable of the Government Internal Control System undermines the positive influence of pressure on corruption. It means that the internal control system of the government which has been created can suppress the effect of internal and external pressure on the Court employees. Instead, the Court employees must be able to manage internal pressure, for instance, they have to acknowledge that as civil servants, they are provisioned with a salary by the regulation since they are paid by the government.

Thus, they must exhibit their performance to serve the community and to uphold justice for all. This statement is in line with the findings of the research conducted by Umar and Irsan which found that the government's internal control system weakens the positive influence on corruption by implementing accrual-based accounting as a moderating variable.

\subsection{The Government Internal Control System (SPIP) Moderates the Effect of Opportunities on Corruption}

The variable of Government Internal Control System (SPIP) does not undermine the positive influence of the variable 'opportunity' on the corruption. It indicates that the existing government internal control system (SPIP) is not able to reduce the opportunities for corruption since the Court employees performed their duties not in accordance with the established SOP (standard operating procedures). There were intention and greed in the perpetrators, enabling the corruption still to be rampant. Therefore, the effectiveness of the Government's Internal Control System is in question. However, this finding is not in line with that of the research conducted by Wulandari and Nuryatno stating that internal control, integrity, independence and professionalism have a positive effect on fraud prevention, while anti-fraud awareness does not.

\subsection{The Government Internal Control System (SPIP) Moderates the Positive Effect of Rationalization on Corruption}

The variable of Government Internal Control System (SPIP) does not undermine the positive influence of the variable 'rationalization' on the corruption. It indicates that the internal control system has not yet run well. It is because the corruptors' common mindset is that accepting gift as gratitude from other parties for the duties and functions they perform is appropriate. In addition, the opportunity (the perpetrators' intention), greed and weak punishment for corruptors make the government's internal control system run less effectively. The perpetrators' rampant justification makes it difficult for the Government Internal Control System to suppress it. Nevertheless, this finding is not in line with that of the research conducted by Aswad, which found that the effectiveness of internal control is able to weaken the positive influence on the tendency of accounting fraud. They found that the effectiveness of internal control is not able to strengthen the negative effect of compliance with accounting rules on the tendency of accounting fraud and the effectiveness of internal control is able to strengthen the negative effect of compensation appropriateness towards accounting fraudulence(Aswad, Hasan, \& Indrawati, 2018).

\subsection{The Government Internal Control System (SPIP) Moderates the Effect of Ability on Corruption}

The Government Internal Control System (SPIP) cannot undermine the positive influence of ability on corruption. The existing Government internal Control System (SPIP) has not been able to reduce corruption. It is because the system is not able to suppress the capabilities of the Court employees, where their positions provide opportunities for committing corruption. In addition, greed and weak existing punishment make the capabilities more powerful so that SPIP is not able to suppress it. Yet, the finding is not in line with that of the research conducted by Darmawan and Darwanis stating that when an internal control is determined, all activities, physical resources, and data can be monitored and under control, the objectives of the organization are carried out, risks are minimized, and information is generated with quality.

\subsection{The Government Internal Control System (SPIP) Moderates the Effect of Integrity on Corruption}

The Government Internal Control System (SPIP) does not strengthen the negative influence of the integrity on corruption. It is because the internal control system is not able to suppress opportunity, rationalization and ability; thus, the Court employees lose their integrity. It results from greed, opportunity (the perpetrators' intention), and rationalization that receiving gratification is not corruption. However, This result is not in line with that of the research conducted by Umar and Irsan (2018) which found that the system of government internal control has a positive effect on corruption prevention by implementation of accrual-based accounting as a moderating variable. 


\section{Conclusions}

1. Pressure has a positive effect on corruption.

2. Opportunities have a positive effect on corruption.

3. Rationalization has a positive effect on corruption.

4. The ability positively influences the occurrence of corruption.

5. Integrity has a negative effect on corruption.

6. The government internal control system (SPIP) undermines the positive influence of pressure on corruption.

7. The government's internal control system does not weaken the positive influence of opportunities on corruption.

8. The government internal control systems does not weaken the positive influence of rationalization on corruption.

9. The government internal control systems does not weaken the positive influence of the ability on corruption.

10. The government's internal control system does not strengthen the negative effect of integrity on corruption.

\section{Acknowledgements}

This paper is dedicated to Magister Akuntansi-University of Trisakti, Jakarta, Indonesia.

\section{References}

Abdullahi, R., \& Mansor, N. (2018). Fraud prevention initiatives in the Nigerian public sector: Understanding the relationship of fraud incidences and the elements of fraud triangle theory. Journal of Financial Crime. https://doi.org/10.1108/JFC-02-2015-0008

Aksa, A. F. (2018). Pencegahan dan Deteksi Kasus Korupsi pada Sektor Publik dengan Fraud Triangle. Jurnal Ekonomi, Bisnis, Dan Akuntansi (JEBA), 20(4). Retrieved from http://jp.feb.unsoed.ac.id/index.php/jeba/article/view/1238

Alam, M. M., Johari, R. J., \& Said, J. (2018). An empirical assessment of employee integrity in the public sector of Malaysia. International Journal of Ethics and Systems, 34(4), 458-471. https://doi.org/10.1108/IJOES-01-2018-0006

Albrecht, W. S., Albrecht, C. O., Albrecht, C. C., \& Zimbelman, M. F. (2012). Fraud examination. South-Western Cengage Learning. https://doi.org/10.1017/CBO9781107415324.004

Association of Certified Fraud Examiner (ACFE). (2017). Survai Fraud Indonesia 2016. ACFE Indonesian Chapter. https://doi.org/10.1201/9781315178141-3

Aswad, H., Hasan, A., \& Indrawati, N. (2018). Faktor-Faktor yang Mempengaruhi Kecenderungan Kecurangan Akuntansi Dengan Keefektifan Pengendalian Internasl Sebagai Variabel Moderasi (Studi pada Perusahaan Perkebunan Kelapa Sawit Swasta di Provinsi Riau). Jurnal Akuntansi, 6(2), 221-234. https://doi.org/10.1017/CBO9781107415324.004

Cressey, D. R. (1964). Delinquency, crime and differential association.

Darmawan, A., \& Darwanis. (2018). Pengaruh sistem pengendalian internal, pemanfaatan teknologi, kompetensi sumber daya manusia dan penerapan sistem akuntansi keuangan daerah terhadap kualitas laporan keuangan SKPA provinsi aceh. Jurnal Ilmiah Mahasiswa Ekonomi Akuntansi (JIMEKA), 3(1), 9-19.

Dewi, K. Y. K., \& Ratnadi, N. M. D. (2017). Pengaruh pengendalian internal dan integritas pada kecenderungan kecurangan akuntansi satuan kerja perangkat daerah kota denpasar. E-Jurnal Akuntansi Universitas Udayana, 18(2), 917-941.

Ghozali, I., \& Fuad. (2014). Structural Equation Modeling, Teori, Konsep dan Aplikasi dengan Program Lisrel 9.10. Badan Penerbit Universitas Diponegoro.

Haryono, U. (2016). Corruption the devil. Jakarta: Penerbit Universitas Trisakti.

Haryono, U., \& Purba, R. B. (2019). Audit forensic lawan korupsi. Jakarta: Penerbit Universitas Trisakti.

Hasanah, N., \& Diana, N. (2018). Analisis pengaruh fraud diamond dan GONE theory terhadap academic fraud (Studi Kasis Terhadap Mahasiswa Program Studi Akuntansi Perguruan Tinggi Negeri dan Perguruan Tinggi Swasta Di Malang). Jurnal Ilmiah Riset Akuntansi, 7(2). https://doi.org/10.1017/CBO9781107415324.004 
Isgiyata, J., Indayani, I., \& Budiyoni, E. (2018). Studi tentang teori GONE dan pengaruhnya terhadap fraud dengan idealisme pimpinan sebagai variabel moderasi: studi pada pengadaan barang/jasa di pemerintahan. Jurnal Dinamika Akuntansi Dan Bisnis, 5(1), 31-42. https://doi.org/10.24815/jdab.v5i1.8253

Jensen, M. C., \& Mecklingm, W. H. (1976). Theory of the firm: Managerial behavior, agency cost and ownership structure. Journal of Financial Economics, 3, 305-360.

Mohd-Sanusi, Z., Mohamed, N., Omar, N., \& Mohd-Nassir, M.-D. (2015). Effects of internal controls, fraud motives and experience in assessing likelihood of fraud risk. Journal of Economics, Business and Management. https://doi.org/10.7763/joebm.2015.v3.179

Ruankaew, T. (2016). Beyond the fraud diamond. International Journal of Business Management \& Economic Research.

Sekaran, U., \& Bougie, R. (2016). Research methods for business, a sikll-building approach. Wiley. https://doi.org/10.13140/RG.2.1.1419.3126

Siahaan, M., Umar, H., \& Purba, R. B. (2019). Fraud star drives to asset misappropriation moderated by internal controls. Journal of Southwest Jiaotong University, 54(4), 1-10.

Tuanakota, T. M. (2010). Akuntansi forensik \& audit investigatif.

Umar, H., Usman, S., \& Purba, R. B. R. (2018). The influence of internal control and competence of human resources on village fund management and the implications on the quality of village financial reports. International Journal of Civil Engineering and Technology.

Umar, H., \& Nasution, M. I. (2018). The Influence of the Government Internal Control System and Internal Audit on Corruption Prevention Mediated By Implementation of Actuals-Based Accounting. Saudi Journal of Business and Management Studies (SJBMS), 359-372. https://doi.org/10.21276/sjbms.2018.3.3.16

Wulandari, D. N., \& Nuryanto, M. (2018). Pengaruh pengendalian internal, kesadaran anti-fraud, integritas, independensi, dan profesionalisme terhadap pencegahan kecurangan. Jurnal Riset Akuntansi Mercu Buana, 4(2), 117. https://doi.org/10.26486/jramb.v4i2.557

Yusof, M. K., Khair, A., \& Simon, J. (2013). Fraudulent Financial Reporting: An Application of Fraud Models to Malaysian Public Listed Companies. A Multidisciplinary Journal of Global Macro Trends, 2(4), 144-160. https://doi.org/10.1353/jda.2014.0042

Zamzam, I., Mahdi, S., \& Ansar, R. (2017). Pengaruh Diamond Fraud dan Tingkat Religiuitas Terhadap Kecurangan Akademik (studi pada mahasiswa S-1 di lingkungan perguruan tinggi se kota Ternate). Akuntansi Peradaban, 3, $1-24$.

\section{Copyrights}

Copyright for this article is retained by the author(s), with first publication rights granted to the journal.

This is an open-access article distributed under the terms and conditions of the Creative Commons Attribution license (http://creativecommons.org/licenses/by/4.0/). 